\title{
Fiction, Docudrama and Journalism in the Globo Group (Grupo Globo): A Memory of the Brazilian Military Dictatorship Directed at the General Public ${ }^{*}$
}

\author{
Mônica Almeida Kornis \\ Fundação Getulio Vargas/CPDOC, Rio de Janeiro, Brazil
}

\begin{abstract}
From the early days of the moving image and its recordings of facts and events considered to be historical, followed by the consolidation of the classic narrative cinema grammar in the 1910s reaffirmed until today by a large part of the television production that turns to the past, without disregarding authorial aesthetic experiences produced especially since the 1920 s, history has been present for over more than a century in several types of media. Movie theaters, people's homes and, nowadays, thanks to new media technology, any and every place are spaces for projecting historical narratives. They are both entertainment-by deploying strategies for constructing a "truth" about the past — and critical reflection, going against a belief in that possibility, in rendering explicit their nature as a language. Since all of these narratives presuppose an audience, a public, within different genres, styles and formats, with more realist overtones, more to the general public's taste, or anti-naturalist, in experiences for smaller audiences, it seems pertinent to discuss these issues considering that audiovisual narratives are powerful agents in constructing a memory of the past. Particularly in this text, we will examine how the most powerful communication enterprise in Brazil - Global Group - had construct a memory of the Brazilian military dictatorship (1964-1985) until 2016.
\end{abstract}

Keywords: Brazilian history, television, memory, media, cinema, national identity, fictional narratives

\section{Research Context}

The author intends to present an overview of his research on the memory of the Brazilian military dictatorship produced by the Globo Group, specifically by Rede Globo (over-the-air network), by Globo Filmes (producer and/or distributor of films for cinema) and by Globo News (news cable channel), discussing the thematic and formal choices that make up each of these narratives. Just as in cinema, television has turned since its early days toward historical narratives in its dramaturgy, and with TV Globo, created in 1965, it would not be different, as we shall see.

\section{Television and Cinema: Fiction and Docudrama}

Addressing the past was a focus of Brazilian teledramaturgy since its early days, initially with the adaptation of Brazilian literature classics set in the times of the Empire and the early days of the Republic. The

\footnotetext{
* Paper presented in the 3rd International Public History Conference. Bogota, Colombia, July 7-9, 2016.

Mônica Almeida Kornis, Ph.D., Professor, Escola de Ciências Sociais/CPDOC, Fundação Getulio Vargas.
} 
realist strategy of television fiction initiated by TV Tupi in 1968 referenced the historical context in terms of cultural and behavioral issues, but it was with TV Globo (a beneficiary of the telecommunications policy implemented during the military dictatorship) from 1969/70 onwards that this realist strategy vigorously imposed itself, with a roster of telenovelas attuned to the national reality, therefore distant from the model adopted by the first television productions of the 1950s (Hamburger, 2005). The miniseries format implemented in 1982 started to address episodes of Brazilian history, consolidating the successful teledramaturgy formula Globo had implemented for the telenovela format and furthering the network's presence as an agent in the construction of a national identity through historical narratives (Kornis, 2011c). Also in the 1970s, despite the fact that the country was under a dictatorship, the allegorical treatment in some telenovelas by playwright Dias Gomes and some situations experienced by characters in the series The big family (A grande familia), written by playwrights Oduvaldo Viana Filho and Armando Costa who, like Dias, had ties to the Communist Party, as well as the documentary experiences of the Globo Reporter (Globo Repórter) program, referred to the context of the time, even critically (Martins, 2011; Sacramento, 2011, 2012; Ridenti, 2000). In summary, productions were attuned to the country's reality and with its history, and this is characteristic of the network's teledramaturgy to this day.

The climate of progressive political openness Brazil experienced in the early 1980s and that culminated in the establishment of a democratic regime (albeit through indirect elections) in 1985 was accompanied by thematic and format changes in TV Globo's fictional production. In the last years of the military dictatorship, the network began to internally discuss the possibility of addressing moments from the country's recent history in its fictional production. The idea that emerged victorious was that of addressing the Juscelino Kubitschek government (1956-1961) —which, starting in the 1980s, was becoming the greatest symbol of Brazilian democracy - in Golden Years (Anos Dourados), by Gilberto Braga (Kornis, 2003). The series aired in 1986 and its epilogue referred in voice-over to the repression and the arrest of one of the characters, an Architecture student, in the mid-1960s. The following year, the telenovela Mandala briefly referred to the debate on "democracy or communism", an allusion to that context. Thus, if in 1983 the network had reported on mobilizations that would lead, in the following year, to the Diretas Já movement, claiming for elections - even identifying it as a musical spectacle due to the strong presence of singers and songwriters on stage-, with the regime change, in 1985, Rede Globo would also begin to "recount" the country's recent history (Kornis, 2001).

Generally speaking, miniseries mainly addressed the theme from the perspective of generational, markedly individual trajectories, a trend more explicit on television than in cinema. This was more evident in two works by Gilberto Braga, Rebel Years (Anos Rebeldes-1992) and to a lesser degree Golden Years (1986), whose titles evoke a return to a past as time over which behavior, everyday life and politics are articulated. The idea of the generational trajectory is also present in Hilda Hurricane (Hilda Furacão-1998), a novel by Roberto Drummond, though the narrative axis of Gloria Perez's teledramaturgy adaptation was Hilda's rebellious behavior and the tensions it created. Amidst personal and family conflicts, with a focus on the generational trajectory, the reference to politics in fiction as an organizing element of the narrative's development is evident in the three titles listed above, even if Golden Years only mentions it as an epilogue, when referring to the 1960s (Kornis, 2001).

Rebel Years was, however, the miniseries that most addressed the dictatorship, from the months that preceded the March, 1964 coup until the year amnesty was declared, in 1979. The focus of the plot was the 
conflicted love story between Maria Lúcia and João Alfredo amidst the portrait of a generation presented through a group of their friends. With different personalities and world views, João was an idealist, whose preoccupation with social justice would lead him to political activism in the 1960s and 1970s, while Maria Lúcia was a well-intentioned but individualistic young woman who desired a stable life, unlike what she experienced because of the ideals espoused by her father, a member of the Communist Party. Within a polarization between individualism and political activism, fiction and history in fiction are organized, and there is a correspondence between the couple's on-again, off-again relationship and the space of politics narrated in the fiction, except when João becomes politically radicalized, at which point clandestinity and police persecution take on the tone of an action and adventure film. Within a domestic, family drama, the narrative organized some landmarks of the country's history from that period, transforming them into icon-facts, with the help of a lot of archive images. Morality and ethics are the basis for this narrative structure, to which the political history is added, constructed within a family drama. These values were in vogue during the democratic and polarized context of the Collor administration, which was questioned for ethical reasons for most of its existence (Kornis, 2004).

Other miniseries refer to the period in a different manner, less vital in constructing the narrative, but still merit being mentioned. Ten years after Hilda, the trajectory of the 1970s generation was present in Dear Friends (Caros Amigos - 2008), by Maria Adelaide Amaral, which portrays a reunion between friends undoubtedly also that of a generation - at the end of the 1980s, specifically in 1989, after the fall of the Berlin Wall. Likewise, the miniseries Decadence (Decadência-1995), written by Dias Gomes, addressed two moments from the military regime, though its focus was a portrait of the country between 1984-based on the national mobilization for direct Presidential elections - and 1992 (Kornis, 2006).

The series format and the comedy programs that began, from 1985 onwards, to incorporate a new generation of actors and thematic innovations, as well as innovations in the television language itself (Figueroa \& Fechine, 2008) influenced the construction of narratives about the military dictatorship in Globo Filmes' film production, starting in the 2000s. Headed by Guel Arraes, this production had as its references parodies of American movies and chanchadas, originating in the network's telenovelas. Initially an assistant director for telenovelas, Arraes was, after a decade, the director of a nucleus that sought to renovate the language of television fiction. Fast-paced editing, references to television production itself, an excessive introduction of verbal, visual and sound information as an anti-illusionist strategy are characteristics of this programming. In the first program, in 1985, titled Unlimited Hustle (Armação Ilimitada), the female character was the daughter of a former political exile, while the program Cassette and Palanet (Casseta e Planeta), which went on the air in 1990, brought professionals from the alternative press with a tradition of criticizing the military regime and using irreverent humor. These professionals had enjoyed a great reach at the time because of their presence in alternative newspapers such as The Lampoon (O Pasquim) and Popular Cassette (Casseta Popular). The dislocation of television language to entertainment cinema that began with Globo Filmes thus consolidated the presence of a production attuned to this aesthetic in two films set during the dictatorship, both at the coup's onset - Kings and rats (Reis e ratos - Mauro Lima, 2012) — and in the beginning of the Médici administration, the most repressive of the 21-year dictatorship-The World Cup is ours (A taça do mundo é nossa - Lula Buarque de Hollanda, 2003), a reference to Brazil's World Cup victory in 1970. In both films, the spirit of adventure moves the conflict, with nods to the police genre. The chronological markers are very defined (1963-1964 and 1970) and express moments of radicalization of the country's political conflicts: in The World 
Cup is ours, the military's presence from 1964 onwards leads to increased tensions between them and "subversive terrorists" amidst celebrations for Brazil's third World Cup title (and also - why not? - to the most repressive moment of the dictatorship, Emilio Garrastazu Médici's rule), while worsening tensions leading up to the coup are dislocated toward the presence of antagonistic international forces (United States x URSS) acting in the country (Kornis, 2015b).

Globo Filmes produced and/or distributed other films that, despite not being based on the television model, reconstructed the period, and therefore deserve to be mentioned. Zuzu Angel (2006), by Sergio Resende, The master of the story ( $A$ dona da história-2004), by Daniel Filho and The year my parents went on vacation $(O$ ano em que meus pais sairam de férias - 2006), by Cao Hamburger, in addition to the documentary Simonal no one knows how hard I struggled (Simonal - ninguém sabe o duro que dei-2009), by Claudio Manoel, Micael Langer and Cavito Leal (Kornis, 2015a).

In the docudrama tradition, the popular program Direct Line (Linha Direta) addressed real cases that took place during the military dictatorship in its segment Justice (Justiça), which ran between 2003 and 2007. The series "Justice" kept the same format as the program that had aired every week since 1999: It sought to reconstruct murders and kidnappings and mixed journalism and dramaturgy within a sensationalist approach. It sought to locate the guilty in the name of justice, with the ultimate goal of re-establishing order, following, therefore, a melodramatic movement. Fast-paced editing, an agile camera, a suspense soundtrack, images saturated with red, interviews with family members and friends that were at times emotional, set the tone for the program, which also sought to "achieve justice" by interviewing lawyers and legal experts. Five cases addressed that time period the most: the biographies of Zuzu Angel (murdered because of her incessant search for the body of her son, Stuart Angel, an activist killed by the government's repressive forces), journalist Wladimir Herzog (likewise killed by the repressive forces), Friar Tito (who committed suicide while in exile because of psychic disorders caused during his time in prison), and Corporal Anselmo (a police informant who pretended to be an activist in the armed struggle against the dictatorship), as well as the episode on the Riocentro Bomb (which was holding a Labor Day musical celebration when bombs went off in its external areas). A set of individual cases which appear as exceptions, among other reasons because they all took place at a time when the regime was becoming more open, a process which started in 1974. Just as in the miniseries, the melodramatic strategy favors individual cases, although, in this instance, with real characters and facts (Kornis, 2011a, 2011b).

\section{Television Journalism}

Within television journalism, the theme was only addressed in 2010 in the cable channel Globo News, which had been created four years before - that is, three years after the last Direct Line program had aired and 15 years after the end of the dictatorship. At the time, journalist Geneton Moraes Neto carried out interviews for the GloboNews Dossier (Dossie GloboNews) program, with influential characters from the regime such as generals Newton Cruz and Leônidas Pires Gonçalves. Within the program's format, there was no overview of the period or even a documentary perspective on that time. There were occasional contextual interventions made by the interviewer through voice-over. These voice-over contributions accompanied black and white images and sounds of marching men, the focus of which were marching boots, in a clear allusion to the military. The program intended to discuss that period, but with a clear revision of the past, in some themes highlighted by the interviewer. 
When the National Truth Commission (Comissão Nacional da Verdade - CNV) began its work in 2012, the year after Dilma Rousseff - herself a political prisoner of the regime for having been part of the leftist organization Vanguarda Popular Revolucionária - was sworn in as President, news about the investigation of human rights violations committed since 1945 began circulating, as was the CNV's goal. While Geneton Moraes had interviewed the former generals and occasionally interviewed former members of the military regime - more recently with the former civilian Minister Celio Borja -, journalist Miriam Leitão reported on the disappearance of political prisoners. In March 2012, she discussed the disappearance of former representative Rubens Paiva, in a program titled "an unfinished story", in consonance with the beginning of the CNV's work. In order to emphasize the issue, and being faithful to the strategy of attracting viewers, the program began by drawing attention to Paiva's kidnapping. Unlike Geneton, Miriam Leitão - a former member of PC do B who was arrested in 1973 and is therefore sensitive to the issue - interviewed people who were part of the government, but also family members and officials from the Dilma administration who had been activists at the time, such as José Genoíno. Additionally, the program largely made use of archive images, a choice more faithful to a style approaching that of documentaries. That same year, Leitão also interviewed CNV's coordinator, Claudio Fonteles, who at the time was researching the archives of the National Information Service.

The theme returned to Globo News two years later, in a special series on the 50th anniversary of the coup led by Geneton Moraes, aired during the four Saturdays of the month of March in 2014. He interviewed several people, among whom former ministers Jarbas Passarinho and João Paulo dos Reis Veloso, in addition to former activists Carlos Eugenio Clemente, Cid Benjamin and Flávio Tavares, the American ambassador to Brazil at the time, Lincoln Gordon, the singer and songwriter Geraldo Vandré and the writer Marcelo Paiva, son of former federal representative Rubens Paiva, murdered during the dictatorship. The range of interviewees was broadened and, with a narrative construction that differed from that of the previous program, the series, in its four moments, approached a traditional documentary model, relaying facts about the coup and the entire dictatorial period. Miriam Leitão interviewed judge Caio Taranto and Rubens Paiva's daughter, still about the Rubens Paiva case, in addition to Pedro Dallari, at the time the final CNV report was published, thus keeping the focus on the investigations into the disappearance of political prisoners. Here, there was a strong emphasis on the search for the truth, unlike Geneton's programs, which directed the interviews with important protagonists of the time towards their current perception of the past, going beyond relaying the facts that took place during the military regime. As an economy journalist, Miriam Leitão also did a program on the period's economic policy.

Also during the month of March 2014, and also as part of the review of the coup's 50th anniversary, several of the network's programs - Start (Starte), Almanac (Almanaque), Archive N (Arquivo N) and Globo Literature (Globo Literatura) - addressed the period, focusing on issues connected to art and culture at the time.

\section{Conclusion}

It is important to note the diversity of the television production - extending to the Globo Group's cinema production through Globo Filmes - beginning at the end of the dictatorship and the beginning of redemocratization, even if the greater impulse came in the 1990s. The first steps were taken in teledramaturgy, but the biggest references would arrive in the 2000s, and more strongly starting in 2003, the year union leader 
and principal figure of the Workers' Party Luís Inácio Lula da Silva was sworn in as President. The segment "Justice" premiered on Direct Line, the film The World Cup is ours was released and the troubled year of 1968 was briefly addressed in the first chapters of the telenovela Lady of Destiny (Senhora do Destino). In the current decade, programs struck a celebratory note in order to address the issue within the journalism of the journalism channel, 2012 and 2014, at a time when the Truth Commission was being set up. In 2012, the film Kings and rats portrayed the context that preceded the military coup and in 2015 a politically correct character in the telenovela Babylon (Babilonia - 2015) occasionally referred to her past as a lawyer for political prisoners at the start of her career.

In addition to acting as an agent for the construction of a national identity whose focus on historical reconstruction is an important element in its fictional serial programming, Rede Globo whitewashes a historical period in which its connections to the regime earned it severe criticism. This process is built and is renewed over time in different ways, and within the different formats, as confirmed, for example, by the presence of the Lula administration Defense Minister, José Viegas, in the Zuzu Angel case in Direct Line Justice. In addition to the editing of his statement acting as a way to punctuate moments in the country's history since 1960, he fulfills the job of guaranteeing that the year 2003 was a new moment for the Armed Forces. It was possibly the confirmation that the country had changed, considering that the Armed Forces were democratic on the year that a factory worker was sworn in as President.

If the generational trajectory molded the period's historical reconstruction in its behavioral, political and at times cultural facets, the focus on unveiling the repression's crimes and armed actions confers a prominent place to politics and to justice, in a movement that converges, in both formats, on a melodramatic reconstruction of the past. Both formats mobilize affection and emotion, in the style of a television spectacle, treated as family and individual dramas, but in two cases there is an impasse in the narrative that points to a process that does not end in the past (Kornis, 2011b). The television and film production centered on parodies fed the theme's treatment within a perspective of casting a glance over the past so as to treat it as something finished, in an even more conservative strategy, even if previously boosted by innovative formal choices. In the news programs, interviews belatedly brought up a few of the barbaric actions committed during the dictatorship, both from the point of view of disappearances and of the defense of a state of exception. Preferentially treated in the narrative of individual cases and briefly addressed, despite the incisiveness of the interviews with agents of the regime.

\section{References}

Figueroa, A., \& Fechine, Y. (2008). Guel Arraes: um inventor no audiovisual brasileiro (Guel Arraes: an inventor in the Brazilian Audiovisual). Recife, CEPE.

Hamburger, E. (2005). O Brasil antenado (The Tuned-In Brazil). Rio de Janeiro, Zahar.

Kornis, M. A. (2001). Uma história do Brasil recente nas minisséries da Rede Globo (A history of the recent Brazil in the Globo Network miniseries). Tese de Doutorado em Artes, Escola de Comunicações e Artes, USP (unpublished Ph.D. Dissertation).

Kornis, M. A. (2003). Ficção televisiva e identidade nacional: Anos Dourados e a retomada da democracia (Television fiction and national identity: Golden years and the return to democracy). In A. A. Abreu, M. A. Kornis, \& F. Lattman-Weltman (Eds.), Mídia e política no Brasil: jornalismo e ficção (Media and politics in Brazil: journalism and fiction) (pp. 75-127). Rio de Janeiro, Editora FGV.

Kornis, M. A. (2004). Anos Rebeldes e a construção televisiva da história (Rebel Years and the television construction of history). In 1964-2004, 40 anos do golpe: ditadura militar e resistência no Brasil (1984-2004, 40 years after the coup: military dictatorship and resistance in Brazil) (pp. 321-328). Rio de Janeiro, Sete Letras. 
Kornis, M. A. (2006). A Rede Globo e a construção da história política brasileira: o processo de retomada democrática em Decadência (The Globo Network and the construction of the Brazilian political history: The return to democracy in Decadence). In A. A. Abreu (Ed.), A democratização no Brasil: atores e contextos (Redemocratization in Brazil: Actors and contexts) (pp. 103-144). Rio de Janeiro, Editora FGV.

Kornis, M. A. (2011a). Linha Direta Justiça e a reconstrução do regime militar brasileiro, ou quando o "fazer justiça" cria uma memória da história (Direct Line Justice and the reconstruction of the Brazilian military regime, or, when "achieving justice" creates a memory of history). In G. Borges, R. L. Pucci, \& F. Seligman (Eds.), Televisão: formas audiovisuais de ficção e de documentário (Television: Audiovisual forms of fiction and documentary) (pp. 39-51). Faro e São Paulo, CIAC/Universidade do Algarve e Socine.

Kornis, M. A. (2011b). As "revelações" do melodrama, a Rede Globo e a construção de uma memória do regime militar (The "revelations" of melodrama, the Globo Network and the construction of a memory of the military regime). Significação: revista de cultura audiovisual (Signification: journal of audiovisual culture), 38(36), 173-193.

Kornis, M. A. (2011c). Ficção televisiva e identidade nacional: o caso da Rede Globo (Television fiction and national identity: The case of the Globo Network). In M. H. Capelato, E. Morettin, M. Napolitano, \& E. T. Saliba (Eds.), História e cinema: dimensões históricas do audiovisual (History and cinema: historical dimensions of the audiovisual) (pp. 97-114). SP, Alameda.

Kornis, M. A. (2015a). Narrativas biográficas sobre o regime militar brasileiro no cinema e na televisão: um despertar de emoções sobre o passado (Biographical narratives about the Brazilian military regime in film and television: Awakening emotions regarding the past). In C. F. Gutfreind (Ed.), Narrar o biográfico: a comunicação e a diversidade da escrita (Narrating the biographical: The communication and diversity of writing) (pp. 188-212). Porto Alegre, Editora Sulina.

Kornis, M. A. (2015b). Da televisão para o cinema: paródia e memória da ditadura militar brasileira (From television to cinema: Parody and memory of the Brazilian military dictatorship). Intexto, 34, 163-177.

Martins, A. F. (2011). O pensamento do documentário na televisão brasileira: a década de 1970 (Documentary thinking in the Brazilian television: The 1970s). Revista Eco-Pós, 14(2), 129-141.

Ridenti, M. (2000). Em busca do povo brasileiro: artistas da revolução, do CPC à era da televisão (In search of the Brazilian people: Artists of the revolution, from the CPC to the age of television). RJ e SP, Editora Record.

Sacramento, I. (2011). Depois da revolução, a televisão: cineastas de esquerda no jornalismo televisivo dos anos 1970 (After the revolution, the television: Leftist filmmakers in the television journalism of the 1970s). São Carlos, Pedro \& João Editores.

Sacramento, I. (2012). Nos tempos de Dias Gomes: a trajetória de um intelectual comunista nas tramas comunicacionais (In the times of Dias Gomes: The trajectory of a communist intellectual in the webs of communication). Tese de Doutorado em Comunicação e Cultura, UFRJ, Rio de Janeiro (Ph.D. Dissertation).

Sobchak, V. (1996). The persistence of history: Cinema, television and the modern event. NY and London: Routledge.

Xavier, I. (2003). O olhar e a cena: melodrama, Hollywood, cinema novo, Nelson Rodrigues (The gaze and the scene: Melodrama, Hollywood, Cinema Novo, Nelson Rodrigues). São Paulo Cosac \& Naify. 